\begin{tabular}{|c|c|c|c|c|c|}
\hline $\begin{array}{l}\text { Modality } \\
\text { (parameters recorded, } \\
\text { unit) } n=20\end{array}$ & $\begin{array}{l}\text { Median } \\
\text { resting } \\
\text { result } \\
\text { (IQR) }\end{array}$ & $\begin{array}{l}\text { Abnormal/ } \\
\text { Normal }\end{array}$ & $\begin{array}{l}\text { Median } \\
\text { squeeze } \\
\text { result } \\
\text { (IQR) }\end{array}$ & $\begin{array}{l}\text { Abnormal/ } \\
\text { Normal }\end{array}$ & $\begin{array}{l}\text { Median } \\
\text { VAS } \\
\text { score } \\
(I Q R)\end{array}$ \\
\hline $\begin{array}{l}\text { HRAM } \\
\text { (Resting/Incremental } \\
\text { Squeeze pressure, } \\
\mathrm{CmH}_{2} \mathrm{O} \text { ) }\end{array}$ & $\begin{array}{l}40.04 \\
(25.6- \\
76.5)\end{array}$ & Abnormal & $\begin{array}{l}81.4 \\
(54.4- \\
147.0)\end{array}$ & Normal & $\begin{array}{l}1 \\
(0- \\
2.8)\end{array}$ \\
\hline $\begin{array}{l}\text { FLIP } \\
\text { (Distensibility index, } \\
\mathrm{mm}^{2} / \mathrm{mmHg} \text { ) }\end{array}$ & $\begin{array}{l}1.6 \\
(0.8-1.7)\end{array}$ & Abnormal & $\begin{array}{l}0.7 \\
(0.5-1.6)\end{array}$ & Abnormal & $\begin{array}{l}0 \\
(0-1)\end{array}$ \\
\hline $\begin{array}{l}\text { AAR } \\
\text { (Opening/Squeeze } \\
\text { opening pressure, } \\
\mathrm{CmH}_{2} \mathrm{O} \text { ) }\end{array}$ & $\begin{array}{l}41.4 \\
(25.1- \\
63.1)\end{array}$ & Abnormal & $\begin{array}{l}79.8 \\
(46.1- \\
124.9)\end{array}$ & Abnormal & $\begin{array}{l}0.5 \\
(0-1)\end{array}$ \\
\hline
\end{tabular}

assessment of anorectal function is crucial in those with FI however, fear of tests/investigations can be a barrier to accessing services. Further qualitative research on patients perceptions/preferences of anorectal investigations and treatments will help to provide education for health practitioners and service users, and hopefully improve the patient journey experience.

\section{PWE-60 UNDIAGNOSED PSYCHOPATHOLOGY IS PREVALENT AND SIGNIFICANT IN PATIENTS ATTENDING A TERTIARY NEUROGASTROENTEROLOGY CLINIC}

${ }^{1}$ Alicia Green, ${ }^{1}$ Inga Daugirdaite*, ${ }^{1,2}$ Qasim Aziz, ${ }^{1,2}$ Asma Fikree. 'Wingate Institute of Neurogastroenterology, London, UK; ${ }^{2}$ Barts Health NHS Trust, London, UK

\subsection{6/gutjpl-2021-BSG.322}

Introduction According to the biopsychosocial model for functional gastrointestinal (GI) disorders, the presence of psychopathology influences symptom presentation and should be targeted in the management plan. We aimed to determine what proportion of patients attending a tertiary neurogastroenterology clinic had evidence of anxiety, depression and eating disorders which had not been previously identified, but which may be very important for treatment strategies.

Methods Consecutive patients attending a tertiary neurogastroenterology clinic completed validated questionnaires to screen for anxiety and depression (HADS-A/D $>11$ ), eating disorders $(\mathrm{SCOFF}>=2)$, avoidant restrictive eating disorders (ARFID using NIAS > 28), personality disorders (SAPAS > 2), GI symptoms (GSRS), visceral sensitivity index (VSI) and quality of life (QOL using SF36). They were asked specifically about a history of anxiety, depression and eating disorders. Questionnaire scores were compared using a Mann Whitney U test - in view of the multiple comparisons a $\mathrm{p}$ value $<0.01$ was considered significant.

Results 186 patients (aged 16-84, 85\% female) completed the questionnaires. 41 patients (22\%) screened positive for depression and $73(39 \%)$ for anxiety, though a third of each of these did not document a diagnosis of depression or anxiety. $22 \%$ screened positive for an eating disorder and $25 \%$ for ARFID, although only 16\% documented a diagnosis of an eating disorder. $48 \%$ screened positive for a personality disorder. Patients who screened positive for depression and anxiety had

\section{Abstract PWE-60 Table 1}

\begin{tabular}{|c|c|c|c|c|c|c|}
\hline & $\begin{array}{l}\text { Negative } \\
\text { depression } \\
\text { screen }\end{array}$ & $\begin{array}{l}\text { Positive } \\
\text { depression } \\
\text { screen }\end{array}$ & $P$ value & $\begin{array}{l}\text { Negative } \\
\text { anxiety } \\
\text { screen }\end{array}$ & $\begin{array}{l}\text { Positive } \\
\text { anxiety } \\
\text { screen }\end{array}$ & $P$ value \\
\hline $\begin{array}{l}\text { Mean overall } \\
\text { GSRS }\end{array}$ & $3.54 \pm 1.10$ & $4.21 \pm 1.11$ & 0.001 & $\begin{array}{l}3.47 \pm \\
1.06\end{array}$ & $\begin{array}{l}4.03 \pm \\
1.18\end{array}$ & 0.001 \\
\hline $\begin{array}{l}\text { Mean GSRS } \\
\text { abdo pain }\end{array}$ & $3.78 \pm 1.27$ & $4.75 \pm 1.19$ & $<0.0001$ & $\begin{array}{l}3.78 \pm \\
1.33\end{array}$ & $\begin{array}{l}4.34 \pm \\
1.22\end{array}$ & 0.005 \\
\hline $\begin{array}{l}\text { Mean GSRS } \\
\text { reflux }\end{array}$ & $3.19 \pm 1.90$ & $3.87 \pm 2.00$ & 0.06 & $\begin{array}{l}3.16 \pm \\
1.95\end{array}$ & $\begin{array}{l}3.63 \pm \\
1.89\end{array}$ & 0.086 \\
\hline $\begin{array}{l}\text { Mean GSRS } \\
\text { indigestion }\end{array}$ & $3.82 \pm 1.51$ & $4.19 \pm 1.53$ & 0.204 & $\begin{array}{l}3.67 \pm \\
1.52\end{array}$ & $\begin{array}{l}4.26 \pm \\
1.46\end{array}$ & 0.01 \\
\hline $\begin{array}{l}\text { Mean GSRS } \\
\text { diarrhoea }\end{array}$ & $3.01 \pm 1.86$ & $4.08 \pm 1.79$ & 0.001 & $\begin{array}{l}2.96 \pm \\
1.84\end{array}$ & $\begin{array}{l}3.69 \pm \\
1.90\end{array}$ & 0.01 \\
\hline $\begin{array}{l}\text { Mean GSRS } \\
\text { constipation }\end{array}$ & $3.70 \pm 1.97$ & $4.15 \pm 1.94$ & 0.213 & $\begin{array}{l}3.66 \pm \\
1.93\end{array}$ & $\begin{array}{l}4.02 \pm \\
2.01\end{array}$ & 0.238 \\
\hline $\begin{array}{l}\text { SF36 General } \\
\text { health }\end{array}$ & $\begin{array}{l}30.85 \pm \\
19.60\end{array}$ & $\begin{array}{l}14.05 \pm \\
10.78\end{array}$ & $<0.0001$ & $\begin{array}{l}31.31 \pm \\
19.77\end{array}$ & $\begin{array}{l}20.35 \pm \\
16.56\end{array}$ & $<0.0001$ \\
\hline $\begin{array}{l}\text { SF36 Physical } \\
\text { functioning }\end{array}$ & $\begin{array}{l}51.50 \pm \\
34.04\end{array}$ & $\begin{array}{l}27.50 \pm \\
27.26\end{array}$ & $<0.0001$ & $\begin{array}{l}51.14 \pm \\
34.52\end{array}$ & $\begin{array}{l}38.06 \pm \\
32.03\end{array}$ & 0.007 \\
\hline $\begin{array}{l}\text { SF36 Social } \\
\text { functioning }\end{array}$ & $\begin{array}{l}47.25 \pm \\
30.66\end{array}$ & $\begin{array}{l}16.07 \pm \\
21.61\end{array}$ & $<0.0001$ & $\begin{array}{l}48.54 \pm \\
31.16\end{array}$ & $\begin{array}{l}27.08 \pm \\
27.91\end{array}$ & $<0.0001$ \\
\hline $\begin{array}{l}\text { SF36 Energy/ } \\
\text { fatigue }\end{array}$ & $\begin{array}{l}31.06 \pm \\
20.84\end{array}$ & $\begin{array}{l}12.02 \pm \\
26.69\end{array}$ & 0.001 & $\begin{array}{l}32.61 \pm \\
21.98\end{array}$ & $\begin{array}{l}17.57 \pm \\
15.83\end{array}$ & $<0.0001$ \\
\hline VSI score & $\begin{array}{l}36.11 \pm \\
18.29\end{array}$ & $\begin{array}{l}45.41 \pm \\
20.60\end{array}$ & 0.006 & $\begin{array}{l}34.81 \pm \\
18.99\end{array}$ & $\begin{array}{l}43.36 \pm \\
18.56\end{array}$ & 0.006 \\
\hline
\end{tabular}

more severe GI symptoms, particularly pain, higher VSI and worse QOL (Table 1).

Discussion/conclusion Simple questionnaire screening identifies a high prevalence of psychopathology in patients attending neurogastroenterology clinics, a third of whom had no documented diagnosis of psychopathology, so this would have been missed by simple history taking. Patients who screen positive for psychopathology have more GI symptoms and worse QOL so it is important to identify this as addressing it may improve GI symptoms. Having a dedicated gastro-psychologist in neurogastroenterology centres would help with screening and managing these difficult conditions yet the majority of UK centres do not have access to this.

\section{PWE-61 AN EARLY EVALUATION OF PARTICIPANT RECRUITMENT AND COMPLIANCE FOLLOWING THE VIRTUALISATION OF RELIEVE IBS-D TRIAL}

${ }^{1}$ Cho Ee $\mathrm{Ng}^{*},{ }^{2} \mathrm{C}$ Howell, ${ }^{2} \mathrm{~A}$ Kemppinen, ${ }^{3} \mathrm{H}$ Forsyth, ${ }^{3} \mathrm{G}$ Richell, ${ }^{2} \mathrm{E}$ Markaryan, ${ }^{4} \mathrm{~J}$ McLaughlin, ${ }^{5} \mathrm{C}$ Knowles, ${ }^{1,3}$ Yan Yiannakou. ${ }^{1}$ University Hospital North Durham, Durham, UK; ${ }^{2}$ EnteroMed Ltd, London, UK; ${ }^{3}$ NIHR patient recruitment centre, Newcastle, UK; ${ }^{4}$ University of Manchester, Manchester, UK; ${ }^{5}$ Queen Mary University of London, London, UK

\subsection{6/gutjnl-2021-BSG.323}

Introduction Irritable bowel syndrome (IBS) is a common condition but recruitment to IBS clinical trials has been challenging due to non-specialist follow-up, poor diagnostic coding, and complexity of ROME IV criteria. The RELIEVE-IBSD study was delivered partly as a traditional site-dependent trial (SDT) and a remote virtual trial (VT). We aimed to compare 


\begin{tabular}{lllll}
\multicolumn{4}{l}{ Abstract } & PWE-61 Table 1 \\
\hline $\begin{array}{l}\text { Trial } \\
\text { format }\end{array}$ & $\begin{array}{l}\text { Pre/post } \\
\text { pandemic } \\
\text { (April 2020) }\end{array}$ & $\begin{array}{l}\text { Number } \\
\text { sites }\end{array}$ & $\begin{array}{l}\text { Recruitment rate } \\
\text { per month }\end{array}$ & $\begin{array}{l}\text { Recruitment rate per } \\
\text { month per site }\end{array}$ \\
\hline $\begin{array}{l}\text { SDT } \\
\text { (typical) }\end{array}$ & Pre-pandemic & 27 & 11.7 & 0.43 \\
$\begin{array}{l}\text { SDT } \\
\text { (enhanced) }\end{array}$ & Pre-pandemic & 1 & 2 & 2 \\
* & Post- & 26 & 3.6 & 0.14 \\
SDT & $\begin{array}{l}\text { pandemic } \\
\text { Post- } \\
\text { pandemic }\end{array}$ & 1 & 23.0 & 23.0 \\
VT & & & \\
\hline
\end{tabular}

*enhanced recruitment techniques including federation-level GP searches, consent-for-contact registries, and advanced media promotions.

recruitment efficacy and study compliance (drop-outs) in the two forms of the study.

Methods RELIEVE IBS-D is a commercially sponsored doubleblind, placebo-controlled, multi-centre study to test the efficacy and safety of intestinal adsorbents in diarrhoea predominant IBS (IBS-D). Recruitment began in November 2018 with a target to recruit 430 participants across 28 sites. In April 2020 , with approximately half the target reached, the pandemic paused or stopped recruitment in many sites. A single site (Newcastle) developed a virtual recruitment process that commenced in September 2020. In total 269 patients were randomised via the SDT and 161 via the VT. Recruitment rates were compared for the SDT pre-pandemic, open sites continuing to recruit SDT post-pandemic and a single site (Newcastle) running a VT. Drop-out rates of the first 80 cases completing the RCT phase of the SDT and VT were compared.

Results In April 2020, 232 participants (53.9\%) had been randomised before the study was paused.

VT started in September 2020 and target achieved in April 2021. Recruitment rates for different periods are in the table.

Analysis of study compliance ( 8 weeks) of the first 80 sequentially randomised participants showed a drop-out rate of $13 / 80(16 \%)$ for the SDT and 4/80 (5\%) for the VT $(\mathrm{p}<0.05)$.

Conclusions Enhanced recruitment techniques can significantly increase recruitment rates. However, the geographical exclusion created by SDTs limits the effectiveness of recruitment, which can be enhanced many-fold by a VT design. Preliminary evidence suggests that VTs may provide lower levels of patient withdrawals. The success of this study has been facilitated by close cooperation of the sponsor and NHS delivery site, together with involvement of patients in trial design.

\section{PWE-62 REPORTING OF COMORBIDITIES AND OVERLAP SYNDROMES IN FUNCTIONAL DYSPEPSIA: REVIEW OF 15 YEARS OF RCTS}

${ }^{1}$ Fabien Wuestenberghs*, ${ }^{2}$ Maria P Eugenicos. 'Université catholique de Louvain; CHU UCL Namur, Department of Gastroenterology and Hepatology, Yvoir, Belgium; ${ }^{2}$ University of Edinburgh; Western General Hospital, Department of Gastroenterology, Edinburgh, UK
Introduction The Rome Foundation stated recommendations in 2016 to report confounding factors in clinical trials concerning functional gastrointestinal disorders (FGIDs) [1]. The aim of our study was to assess the reporting of different comorbidities and overlap syndromes in patients with functional dyspepsia (FD).

Methods Randomised controlled trials (RCTs) that included adult patients with FD according to Rome criteria were selected via MEDLINE (PubMed ${ }^{\circledR}$ ) and Scopus between 2006 and 2021. Characteristics of the trials and the patients, exclusion criteria, psychological factors, other FGIDs, somatic disorders, and non-gastrointestinal (GI) diseases were all recorded. We analysed the level of reporting of these comorbidities, focussing on the most frequent (gastro-oesophageal reflux disease (GORD), irritable bowel syndrome (IBS), anxiety, depression, Helicobacter pylori infection, diabetes mellitus). The study selection and data extraction were performed by FW; the systematic review was registered in PROSPERO (CRD42021235219).

Results 108 articles were included in the final analysis. Clinical trials were mainly conducted in Asia (76.9\%) and involved a complementary and alternative medicine treatment in $45.4 \%$ of the cases. The mean number of reported comorbidities was 2.44 ( $\pm 1.23 \mathrm{SD})$. Only one paper reported all six comorbidities. $96.3 \%$ of the papers reported at least one comorbidity. $22.2 \%$ of papers reported anxiety, and $24.1 \%$ reported depression. $63.0 \%$ of the papers reported an overlap with GORD and $43.5 \%$ with IBS. $H$. pylori gastritis and diabetes mellitus were reported in $54.6 \%$ and $37.0 \%$ of the papers respectively. There was no reported overlap with non-GI comorbidities, but for headaches that were reported in $2.8 \%$ of the papers. Representation of the reporting of different comorbidities is shown in Figure 1. The reporting of overlaps and comorbidities during the study period remained unchanged.

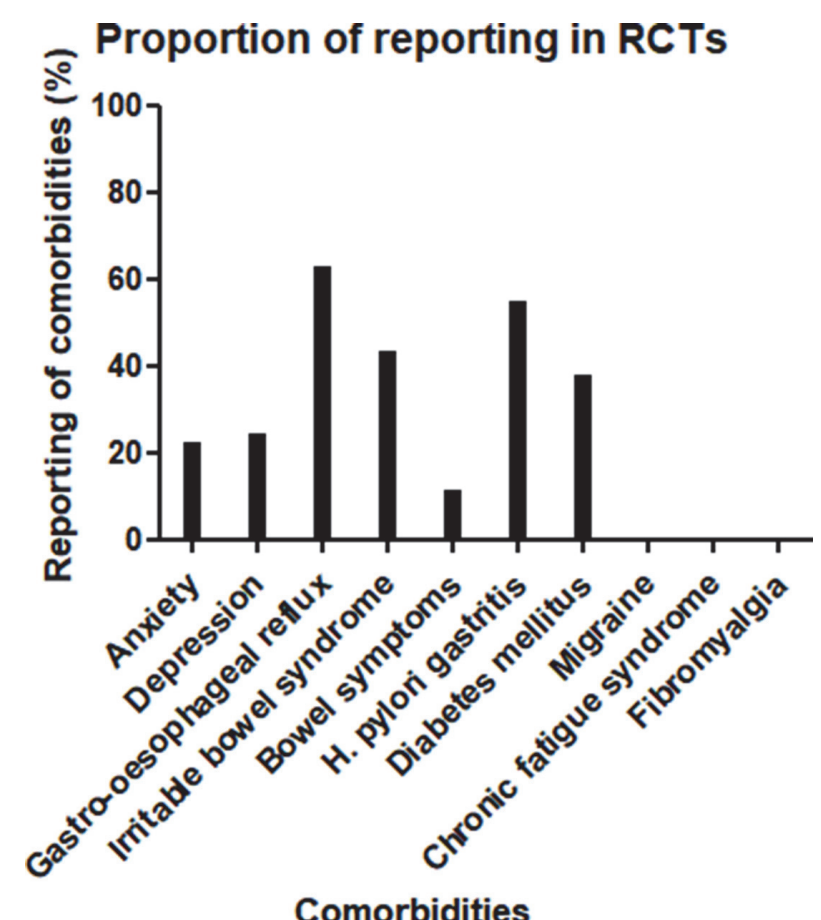

Abstract PWE-62 Figure 1 Representation of the proportion of the articles reporting each comorbidity 